Original Research Article

\title{
Screening of a novel furan compound for its antidepressant activity in albino mice
}

\author{
Jayakumar JK $^{1 *}$, Supriya ${ }^{2}$, Nityakarnam ${ }^{3}$, Kishorekumar ${ }^{4}$
}

\begin{abstract}
${ }^{1}$ Department of Pharmacology,
Sri Devaraj Urs Medical

College, Tamaka, Kolar,

Karnataka - 563101, India

${ }^{2}$ Department of Pharmacology,

Sri Sai Dental College and

Research Institute, Shahapuram,

Srikakulam, Andhra Pradesh,

India

${ }^{3}$ Department of Pharmacology,

Adhiparasakthi Institute of

Medical Sciences and Research,

Tamil Nadu - 603319, India

${ }^{4}$ Department of Pharmacology,

PES Institute of Medical

Sciences and Research,

Kuppam, Andhra Pradesh -

517425, India
\end{abstract}

Received: 29 October 2016

Accepted: 04 November 2016

*Correspondence to:

Dr. Jayakumar JK,

Email: drjkshapur@gmail.com

Copyright: () the author(s), publisher and licensee Medip Academy. This is an openaccess article distributed under the terms of the Creative Commons Attribution NonCommercial License, which permits unrestricted noncommercial use, distribution, and reproduction in any medium, provided the original work is properly cited.

\begin{abstract}
Background: Depression is a common chronic recurrent syndrome, characterized by apathy, loss of energy, retardation of thinking and activity, as well as profound feelings of gloominess, despair and suicidal ideation. The present study aimed to evaluate the antidepressant activity of synthesized novel furan compound by using forced swimming test (FST) and tail suspension test (TST).

Methods: The antidepressant activity was studied in albino mice using FST and TST. Fluoxetine $(20 \mathrm{mg} / \mathrm{kg})$ were used as standard drugs and test drug novel furan compound $(5,10,20 \mathrm{mg} / \mathrm{kg})$ was used as test drug. A total of 60 mice were selected for the study and utilized 30 mice in each model. Animals were divided into five groups consisting of 6 animals in each. Control group received $10 \%$ tween 80 orally; standard group received fluoxetine $20 \mathrm{mg} / \mathrm{kg}$ orally; test group 1 received $5 \mathrm{mg} / \mathrm{kg}$ substituted furan compound orally; test group 2 received $10 \mathrm{mg} / \mathrm{kg}$ substituted furan compound orally; test group 3 received 20 $\mathrm{mg} / \mathrm{kg}$ substituted furan compound orally.

Results: In FST the low dose test compound had shown the percentage inhibition of $75.5 \%$ which was comparable to percentage inhibition of standard drug fluoxetine $-82 \%$. In TST the test group- 1 had produced $66.6 \%$, test group$283.3 \%$ and test group-3 produced $100 \%$ protection against passive behavior (immobility). The percentage of protection produced by highest dose was equal to standard drug fluoxetine against passive behavior.

Conclusions: It can be concluded that the test drug has produced significant inhibition in duration of immobility by FST and also had significant protection against passive behavior. Hence substituted furan had potential antidepressant activity.
\end{abstract}

Keywords: Antidepressant activity, Novel furan compound, FST, TST

\section{INTRODUCTION}

Depression is one of the most common psychiatric disorders. According to $\mathrm{WHO}$, depression is expected to become the second leading cause of disease related disability by the year 2020 , following heart disease. ${ }^{1}$

The goal of pharmacologic treatment of depression is the resolution of current symptoms (i.e. remission) and the prevention of further episodes of depression (i.e., relapse or recurrence). ${ }^{2}$

In spite of the availability of anti-depressant drugs like tricyclic anti-depressants, selective reversible inhibitors of monoamine oxidase-A (MAO-A), selective serotonin reuptake inhibitors (SSRIs) and selective nor adrenaline reuptake inhibitors (SNRIs), depression continues to be a major medical problem. Insomnia and loss of libido with 
SSRIs and tolerance and physical dependence with tricyclic anti-depressants are very common adverse effects. ${ }^{3,4}$ Newer generations of antidepressants have provided pharmacologic interventions that are effective and better tolerated than older agents.

Clinically used antidepressants have several limitations and side effects which demand continuous development of novel, efficient, and safe drugs for the treatment of depression. In this study, a novel substituted furan derivative was synthesized and focused to assess its antidepressant activity at three doses $5 \mathrm{mg} / \mathrm{kg}, 10 \mathrm{mg} / \mathrm{kg}$ and $20 \mathrm{mg} / \mathrm{kg}$ by using forced swimming test and tail suspension test models.

\section{METHODS}

\section{Animals}

Swiss albino male mice of 20-25 g were selected and maintained for 7 days in the animal house under standard conditions. The animals were fed with standard rat pellet and water ad libitum. The animals were allowed to acclimatize to laboratory conditions. All the experiments were conducted after obtaining permission from the Institutional Animal Ethics committee (IAEC).

\section{Antidepressant activity}

The synthesized test compound was screened for antidepressant activity by tail suspension method and forced swimming test in albino mice. ${ }^{5,6}$ A total of 60 mice were selected for the study, 30 mice in each method. Animals were divided into five groups consisting of 6 animals in each. Control group received $10 \%$ tween 80 orally; standard group received fluoxetine $20 \mathrm{mg} / \mathrm{kg}$ orally; test group 1 received $5 \mathrm{mg} / \mathrm{kg}$ substituted furan compound orally; test group 2 received $10 \mathrm{mg} / \mathrm{kg}$ substituted furan compound orally; test group 3 received $20 \mathrm{mg} / \mathrm{kg}$ substituted furan compound orally.

\section{Forced swim test (FST)}

Depression was produced in albino mice by forcing them to swim individually in a glass jar $\left(25 \times 12 \times 25 \mathrm{~cm}^{3}\right)$ containing fresh water of $15 \mathrm{~cm}$ height and maintained at $25^{\circ} \mathrm{C}\left( \pm 3^{\circ} \mathrm{C}\right)$. After an initial 2 minute period of vigorous activity, each animal assumed a typical immobile posture. A mouse was considered to be immobile when it remained floating in the water without struggling, making only minimum movements of its limbs necessary to keep its head above water. The total duration of immobility was recorded during the next 4 min of total 6 min test. A decrease in the duration of immobility is indicative off an antidepressant like effect. Duration of immobility is measured in controls and animals treated with various doses of a test drug or standard.

$$
\text { Duration of immobility }=\frac{\text { Standard }- \text { control }}{\text { Control }} \times 100
$$

\section{Tail suspension test (TST)}

Mice are housed in plastic cages for at least 10 days prior to testing in a $12 \mathrm{~h}$ light cycle with food and water freely available. Animals are transported from the housing room to the testing area in their own cages and allowed to adapt to the new environment for $1 \mathrm{~h}$ before testing. Groups of 6 animals are treated with the test compounds or the vehicle orally $60 \mathrm{~min}$ prior to testing. For the test the mice are suspended on the edge of a shelf $58 \mathrm{~cm}$ above a table top by adhesive tape placed approximately $1 \mathrm{~cm}$ from the tip of the tail. The duration of immobility is recorded for a period of $5 \mathrm{~min}$. Mice is considered immobile when they hang passively and completely motionless for at least $1 \mathrm{~min}$. The percentage of animals showing the passive behavior was counted and compared with vehicle treated controls.

\section{Statistical analysis}

Values obtained for forced swimming test was given as mean \pm SD. All the groups were analysed by one-way ANOVA followed Dunnet's multiple comparison test. P $<0.05$ was considered statistically significant. The values obtained in tail suspension test were given as percentage of animals protected against passive behavior.

\section{RESULTS}

Table 1: Effect of test compound on duration of immobility and percentage inhibition in mice using FST.

\begin{tabular}{|c|c|c|}
\hline Groups & Mean ( in sec) \pm SD & $\%$ Inhibition \\
\hline $\begin{array}{l}\text { Control group } \\
\text { ( } 10 \% \text { tween } \\
80 \text { orally) }\end{array}$ & $142.33 \pm 10.01$ & 100 \\
\hline $\begin{array}{l}\text { Standard } \\
\text { group } \\
\text { (fluoxetine } 20 \\
\text { mg/kg orally) }\end{array}$ & $25.33 \pm 5.46^{\mathrm{a}}$ & 82.20 \\
\hline $\begin{array}{l}\text { Test group-1 } \\
\text { (test drug } 5 \\
\mathrm{mg} / \mathrm{kg} \text {, orally) }\end{array}$ & $35.50 \pm 23.23^{b}$ & 75.05 \\
\hline $\begin{array}{l}\text { Test group-2 } \\
\text { (test drug } 10 \\
\mathrm{mg} / \mathrm{kg} \text {, orally) }\end{array}$ & $58.16 \pm 26.38^{b}$ & 59.13 \\
\hline $\begin{array}{l}\text { Test group-3 } \\
\text { (test drug } 20 \\
\mathrm{mg} / \mathrm{kg} \text {, orally) }\end{array}$ & $53.16 \pm 9.74^{\mathrm{a}}$ & 62.65 \\
\hline
\end{tabular}

\section{Forced swimming test}

A significant decrease in duration of immobility in mice was observed in test groups when compared to control group. The medium dose of test compound $(10 \mathrm{mg} / \mathrm{kg})$ exhibited a signification reduction in immobility and 
percentage of inhibition compared to other test group of animals $(5 \mathrm{mg} / \mathrm{kg} ; 20 \mathrm{mg} / \mathrm{kg})$ as shown in Table 1 .

\section{Tail suspension test}

Table 2 describes the number of animals showing passive behavior (immobility) and number of animals protected against passive behavior in percentages. Fluoxetine and test drug in high dose $(20 \mathrm{mg} / \mathrm{kg})$ produced $100 \%$ protection against passive behavior comparably and equal to fluoxetine. The medium dose test compound (10 $\mathrm{mg} / \mathrm{kg}$ ) had produced $83 \%$ protection against passive behavior and the low dose test compound $(5 \mathrm{mg} / \mathrm{kg})$ had produced $66.6 \%$ protection against passive behavior.

\section{DISCUSSION}

Depression is an important psychiatric disorder that affects individuals' quality of life and social relations directly. It is characterized by emotional symptoms such as hopelessness, apathy, loss of self-confidence, sense of guilt, indecisiveness, and amotivation, as well as biological symptoms like psychomotor retardation, loss of libido, sleep disturbances, and loss of appetite. ${ }^{7}$

Table 2: Effect of test compound on percentage of animals showing and protected against passive behavior in mice using TST.

\begin{tabular}{|llll|l|}
\hline Group & $\begin{array}{l}\text { No. of animals } \\
\text { showing passive } \\
\text { behavior } \\
\text { (immobility) }\end{array}$ & $\begin{array}{l}\text { \% of animals } \\
\text { showing passive } \\
\text { behavior } \\
\text { (immobility) }\end{array}$ & $\begin{array}{l}\text { No. of animals } \\
\text { protected against } \\
\text { passive behavior }\end{array}$ & $\begin{array}{l}\text { of animals } \\
\text { protected } \\
\text { against passive } \\
\text { behavior }\end{array}$ \\
\hline $\begin{array}{l}\text { Control group (10\% tween } \\
80 \text { orally) }\end{array}$ & $6 / 6$ & 100 & $0 / 6$ & 0 \\
\hline $\begin{array}{l}\text { Standard group (fluoxetine } \\
20 \text { mg/kg orally) }\end{array}$ & $0 / 6$ & 0 & $6 / 6$ & 100 \\
\hline $\begin{array}{l}\text { Test group-1 (test drug 5 } \\
\text { mg/kg, orally) }\end{array}$ & $2 / 6$ & 33.33 & $4 / 6$ & 66.6 \\
\hline $\begin{array}{l}\text { Test group-2 (test drug } 10 \\
\text { mg/kg, orally) }\end{array}$ & $1 / 6$ & 16.66 & $5 / 6$ & 83.3 \\
\hline $\begin{array}{l}\text { Test group-3 (test drug } 20 \\
\text { mg/kg, orally) }\end{array}$ & $0 / 6$ & 0 & $6 / 6$ & 100 \\
\hline
\end{tabular}

This study was conducted to assess the antidepressant activity of novel furan compound in albino mice in FST and TST were used for this study. Exposure to stress plays an important role in depression. ${ }^{8}$ These animal models produce physical stress and lead to depression. TST, FST models of depression which provides a rapid and reliable behavior screening test for antidepressants. The immobility has been expected to reflect a state of behavioral despair and failure to adapt to the stress. ${ }^{9}$ Antidepressant drugs decrease immobility time in both FST and TST. ${ }^{10}$

Fluoxetine was used as a standard drug for both models in this study. It is selected as second standard drug because it acts by selectively inhibiting reuptake of serotonin. ${ }^{11}$ The antidepressant activity of the test drug evaluated in this study was a novel furan compound. A number of furan compounds were proved of having significant antidepressant activity. In the present study the test drug showed a significant antidepressant activity when compared with control group (received $10 \%$ tween 80).

The FST model is the more widely used animal model for screening antidepressant acitivity. ${ }^{5}$ Fluoxetine showed a significant antidepressant effect. The test drug at different doses $(5 \mathrm{mg} / \mathrm{kg}, 10 \mathrm{mg} / \mathrm{kg}$ and $20 \mathrm{mg} / \mathrm{kg}$ ) significantly decreases the duration of immobility by 35, 58, 53 seconds respectively when compared with control group (142 seconds). Activity of test drug at medium dose showed significant effect compared other two test doses.

To confirm the results obtained in the FST, many researchers have used in their experiments the tail suspension test (TST). ${ }^{6}$ The tail suspension test has become one of the most widely used models for assessing antidepressant-like activity in mice. Fluoxetine and test drug in high dose $(20 \mathrm{mg} / \mathrm{kg})$ produced $100 \%$ protection against passive behaviour. The low and medium dose of test compound $(5 \mathrm{mg} / \mathrm{kg}, 10 \mathrm{mg} / \mathrm{kg}$ ) had produced $66.6 \%$ and $83 \%$ protection against passive behavior respectively. All doses have produced significant antidepressant activity and efficacy was proportionate to the dose against activity.

\section{CONCLUSION}

Three different doses of test compound $(5 \mathrm{mg} / \mathrm{kg}, 10$ $\mathrm{mg} / \mathrm{kg}$ and $20 \mathrm{mg} / \mathrm{kg}$ ) exhibited antidepressant activity in mice in FST and TST model. The test drug had produced 
significant inhibition by forced swimming test and also has significant efficacy in affording protection against passive behavior.

Funding: No funding sources

Conflict of interest: None declared

Ethical approval: The study was approved by the Institutional Ethics Committee

\section{REFERENCES}

1. Lopez AD, Murray CJ. The global burden of disease, 1990-2020. Nature medicine. 1998;4(11):1241-3.

2. Londhe VP, Nipte SS, Bandawane DD, Chaudhari PD. Screening methods of antidepressants with an Epigrammatic record of research did on Herbal and synthetic drugs. IJPI'S J pharmacol Toxicol. 2011;1(5):61-74.

3. Meti V, Ruckmani A, Chandrashekar K, Konda VGR, Madhavi E, Swati B, et al. Antidepressant activity of ethanolic extract Piper betle leaves in mice. Current Res Neurosci. 2012;2(1):11-6.

4. Gireesh KS, Debapriya G, Muruganandam AV, Vinod KJ, Sairam K. Antidepressant activity of Asparagus racemosus in rodent models. Pharmacol Biochem Behav. 2009;91:283-90.

5. Porsolt RD, Bertin A, Jalfre M. Behavioral despair in mice: a primary screening test for antidepressants. Arch Int Pharmacodyn Ther. 1977;229:327-36.
6. Steru L, Chermat R, Thierry B, Simon P. The tail suspension test: a new method for screening antidepressants in mice. Psychopharmacol (Berl). 1985;85:367-70.

7. Ashok Kumar BS, Lakshman K, Velmurugan C, Sridhar SM, Gopisetty S. Antidepressant Activity of Methanolic Extract of Amaranthus Spinosus. Basic Clin Neurosci. 2014 Winter; 5(1):11-7.

8. Ahmed Amany AE, Al-Rashed Nawal M, AlRasheed Nouf M. Antidepressant-like activities of rosiglitazone in the rat forced swim and the mouse tail suspension tests. Saudi Pharma J. 2009;1(17):5161.

9. Plaznik A, Tamborska E, Hauptmann M, Bidzinski A, Kostowski W. Brain neurotransmitter systems mediating behavioral deficits produced by inescapable shock treatment in rats. Brain Res. 1988;447:122-32.

10. Manavi C, Pinki V, Gautam P. Comparative evaluation of Bacopa monniera and Panax quniquefolium in experimental and depressive models in mice. Indian J Exp Biol. 2010;48:306-31.

11. Ramana Murty Kadali SLDV, Das MC, Srinivasa Rao ASR, Karuna Sri G. Antidepressant Activity of Brahmi in Albino Mice. J Clin Diagn Res. 2014;8(3):35-7.

Cite this article as: Jayakumar JK, Supriya, Nityakarnam, Kishorekumar. Screening of a novel furan compound for its antidepressant activity in albino mice. Int J Basic Clin Pharmacol 2016;5:2389-92. 